\title{
A inclusão digital do educador
}

Recebido em 21.12.2012. Aprovado em 28.12.2012 Avaliado pelo sistema double blind review

\author{
Rose Rodrigues Silva Morelli \\ firminalinda@yahoo.com.br \\ Colégio Estadual Jean Piaget - São Bernardo do Campo -SP - Brasil.
}

\section{Resumo}

O Plano de Empreendimento aqui apresentado fará com que nossa escola EE Jean Piaget passe por uma profunda reformulação na maneira do professor preparar suas aulas. Esse professor uma vez mais seguro em utilizar as novas tecnologias irá estabelecer um contato mais próximo com a realidade do seu aluno, tornando suas aulas mais atraentes, dinâmicas e envolventes. A Inclusão Digital do Educador caracterizará um ponto de partida, onde o retorno esperado será a melhoria na aprendizagem e elevação dos índices nas avaliações externas como SARESP e SAEB. Estaremos focando nos alunos considerados abaixo do básico nas disciplinas de Língua Portuguesa e Matemática. A ideia do nosso Projeto é contratar um profissional Técnico da área de informática para a capacitação de nossos professores. A capacitação ocorrerá em três etapas, nos períodos de ATPC às quartas-feiras na própria escola. Para que tal evento ocorra supriremos 0 nosso laboratório de informática já existente com novos computadores e periféricos. Serão feitas novas instalações e adequações e para isso precisaremos pouco mais de setenta mil reais conforme nossos planejamentos, pois, em se tratando de uma escola estadual contamos também com recursos e investimentos do próprio governo estadual. Temos professores determinados e desejosos em aprender a fazer o uso das novas ferramentas, pois, sempre que esses professores presenciam atividades feitas por dois de seus colegas já familiarizados com as mídias, querem poder fazer o mesmo, mas esbarram no medo . Medo de errar, de saber menos que seu aluno, de utilizar o equipamento de forma errada, enfim, medo de apropriar-se das novas ferramentas. Essa capacitação partirá do básico. 0 objetivo é capacitarmos em 100\% nossos professores e fazê-lo utilizar tudo que aprendeu diretamente com seu aluno na preparação das suas aulas e na comunicação com o educando. Com isso esperamos que a aprendizagem sofra um impacto de modo a elevar os índices de aprovação internos e externos .

O fato da nossa escola ter sido contemplada com o Programa de Ensino Integral nos fez pensar que com todo o investimento que já está ocorrendo, com laboratórios, salas de vídeo, computadores, etc., era necessário envolver o professor nisso tudo. Dessa forma surgiu esse projeto partindo de um pedido dos próprios educadores visando melhorias na aprendizagem e nos resultados.

Palavras-chaves: Educação. Inclusão Digital. Tecnologias de ensino. Plano de empreendimento. 


\section{A inclusão digital do educador}

\section{Contexto da escola}

Escola Estadual Jean Piaget fundada em 1979 e localizada no Jardim Detroit em São Bernardo do Campo ISP. São 435 alunos atendidos nas séries do ciclo II $5^{\mathrm{a}}$ a $8^{\mathrm{a}}$ série e Ensino Médio Regular do $1^{\circ}$ ao $3^{\circ}$ ano.
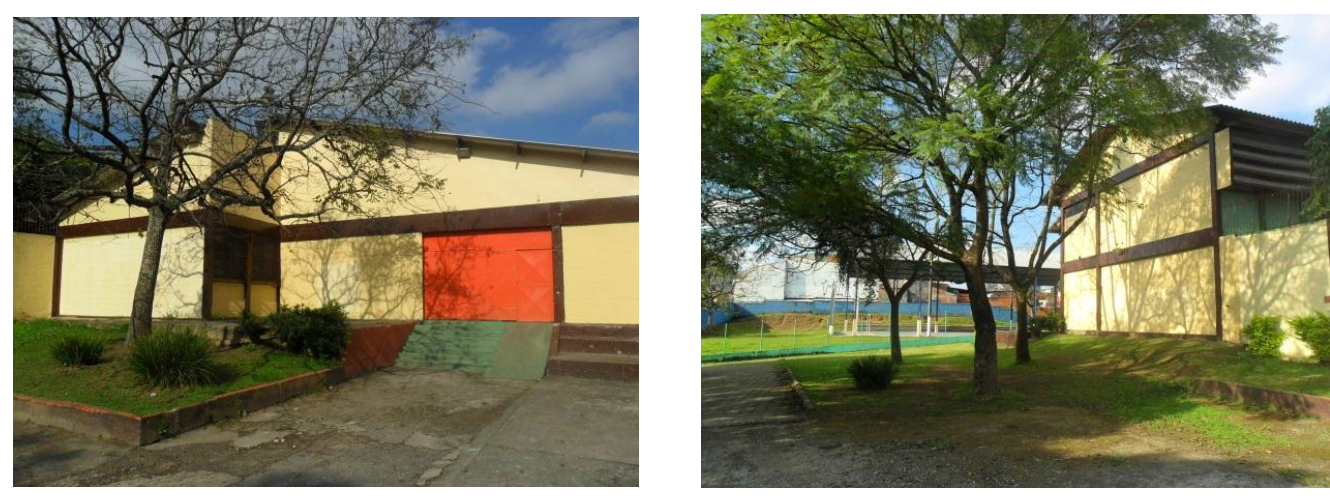

Figura 1: Fotos da fachada e da lateral da Escola.

Missão: Assegurar a frequência e permanência do aluno na escola, levando o educando a sentir a escola como uma extensão da sua vida cotidiana.

Visão: Ao orientarmos o educando ele será capaz de fazer escolhas, traçar caminhos e atingir metas que visem de forma crítica e consciente modificar o meio em que vive onde através do projeto de vida que elaborar, seja ético e cidadão conhecedor dos seus direitos e deveres. A EE Jean Piaget será reconhecida até 2016 como uma escola com Excelência em Gestão e será sinônimo de Qualidade em Educação.

\section{Histórico da Instituição}

A escola Jean Piaget inicialmente foi construída para atender Educação Infantil e Ensino Fundamental Ciclo I, atendendo com o nome de EEPG Jardim Detroit, inaugurada em 1979 com a presença do Prefeito Tito Costa. Ao passar a atender apenas o Ensino Fundamental II, a escola mudou de nome, pois, já não pertencia mais ao município e sim ao Estado. Passou então a se chamar EE Jean Piaget, em 1982.

Escola com estrutura grande e espaçosa própria para Educação Infantil. Hoje, atendendo Fundamental II e Ensino Médio, encontramos problemas com segurança e dificuldade em manter o espaço livre de matos, devido a pouca verba.

\section{Localização e caracterização da escola}

A Escola Estadual Jean Piaget, está inserida em um bairro da periferia de São Bernardo do Campo. Há dois anos havia uma grande quantidade de famílias que moravam em barracos encostados ao muro da escola. Todos foram retirados esse ano (2013) e transferidos para moradias populares em um programa de habitação da cidade. Nossos alunos passaram a vir de outros bairros. A má fama da escola exigiu ações imediatas da nova gestão. Foi preciso antes de se pensar em aprendizagem, que deveria ser o foco da escola, afastar traficantes, trazer a comunidade de volta para escola.

Conseguimos iniciar esse processo que certamente influenciou diretamente na aprendizagem dos alunos. Nosso índice nas avaliações externas foi baixo e não atingimos a meta de 2,29, ficando abaixo dos resultados da diretoria de ensino, das escolas municipais e do Estado. Hoje, ao assumir a gestão dessa escola, tomamos ações para corrigir o fluxo e evasão. Conseguimos diminuir a evasão em pelo menos $30 \%$, pois detectamos que os alunos pedem transferência porque mudam de Estado ou município, sendo que não tivemos nesse ano transferência por descontentamento com a escola. 


\section{Caracterização dos professores}

Apenas cinco dos nossos 28 professores são efetivos. Até o ano anterior havia grande rotatividade de professores, porém, nesse ano o problema foi sanado. No próximo ano a escola fará parte do programa de escolas em Tempo Integral. Já estamos com várias intenções de vaga o que para nós é um indicador de que os pais estão confiando mais nas ações da nova gestão. A maioria dos atuais professores fez inscrição para a Escola em Tempo Integral e o principal fator para a adesão foi o salário maior.

\begin{tabular}{|c|c|c|}
\hline DISCIPLINAS & $\begin{array}{c}\text { NÚMERO DE PROFESSORES } \\
\text { ENSINO FUNDAMENTAL }\end{array}$ & $\begin{array}{c}\text { NÚMERO DE PROFESSORES } \\
\text { ENSINO MÉDIO }\end{array}$ \\
\hline Língua Portuguesa & 1 & 1 \\
\hline Matemática & 1 & 1 \\
\hline Ciências & 1 & 1 \\
\hline História & 1 & 1 \\
\hline Geografia & 1 & 1 \\
\hline Arte & 2 & 1 \\
\hline Inglês & 1 & 1 \\
\hline Ed. Física & 1 & 1 \\
\hline Sociologia & - & 1 \\
\hline Filosofia & - & - \\
\hline Biologia & - & - \\
\hline Física & - & 1 \\
\hline Química & & 1 \\
\hline
\end{tabular}

Alguns dos nossos professores lecionam tanto para o Ensino Fundamental como para o Médio. Nossa necessidade maior hoje seria ter um professor habilitado para a área de Ed. Física e Sociologia ambos no Ensino Médio. Como nossa escola possui poucas turmas o número de professores é suficiente.

\section{Caracterização dos alunos e comunidade}

A população no entorno da escola é carente, mas tem característica empreendedora, cada espaço é ocupado por um micro comércio ou prestadores de serviços. A grande maioria das famílias faz parte do Programa Bolsa Família. Muitos pais não são alfabetizados, o que dificulta o acompanhamento dos trabalhos escolares dos filhos.

No primeiro bimestre procuramos fazer um levantamento de alunos com idade avançada para a série e em reunião com os pais esclarecemos que é possível que o filho seja reclassificado para a série seguinte mediante uma avaliação de aprendizagem. Com isso conseguimos adequar a idade série dos alunos em $80 \%$. Hoje os alunos são distribuídos em séries, pois, nossa cidade ainda não trabalha com o termo ano. 


\section{A inclusão digital do educador}

\section{Abaixo nosso Q.E (Quadro Escolar)/2013}

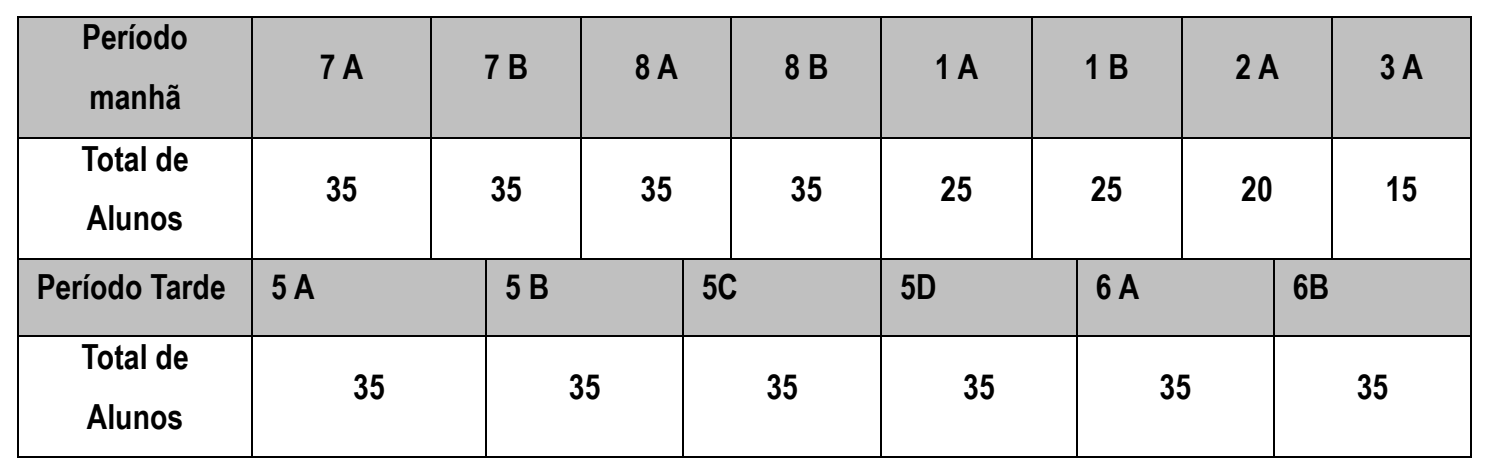

Atualmente são 435 alunos matriculados. Diferente do ano anterior quando até então a escola perdia por transferência sempre duas turmas de quinta série por descontentamento pela escola.

\section{Identificação do problema ou da oportunidade}

Analisando os resultados de Língua Portuguesa do SARESP 2012, nota-se que o número de alunos abaixo do básico aumentou consideravelmente no Ensino Médio. No Ensino Fundamental, também houve aumento no número de alunos abaixo do básico. No entanto, o que mais chama a atenção é a elevação do índice de alunos no estágio básico, em sua maior parte alunos que nos anos anteriores se encontravam no estágio adequado.

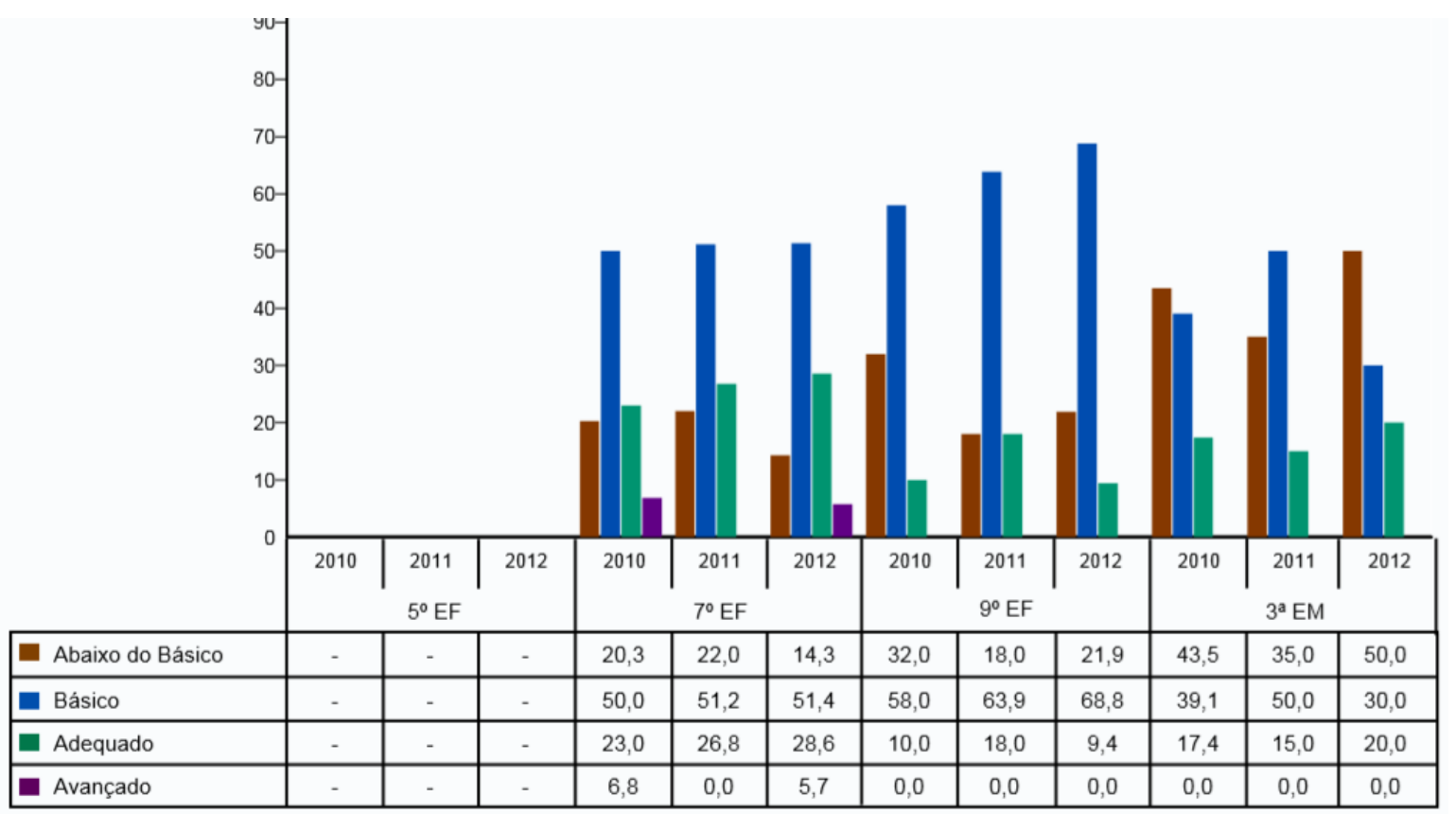

Figura 2.1 - Comparação do percentual de alunos nos níveis da Escala de Proficiência no SARESP 2010 a 2012 - Língua Portuguesa 


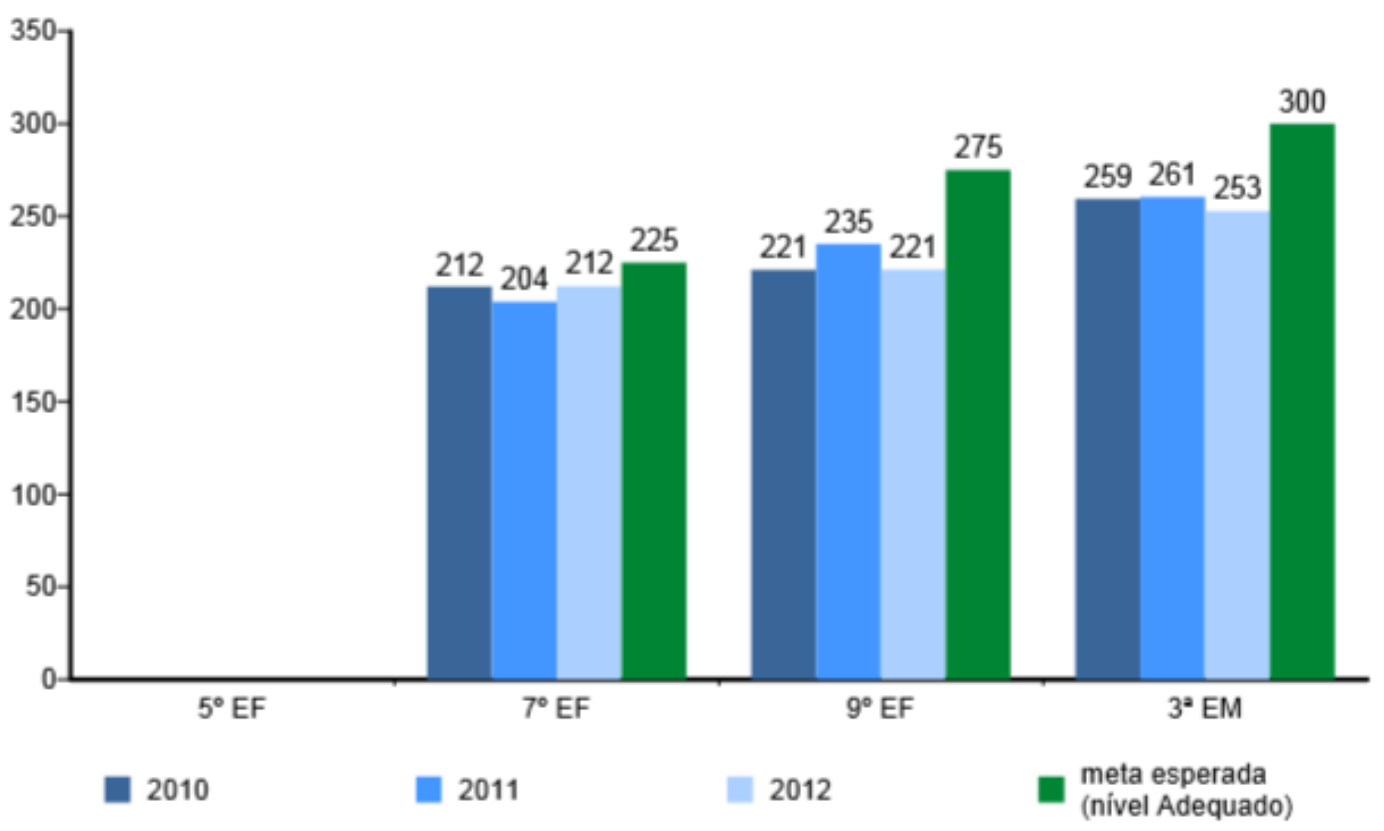

Figura 2.2 - Comparação entre as médias de proficiência dos alunos nas edições de 2010 e 2012 e com a meta esperada no SARESP - Língua Portuguesa

Além disso, há problemas também com a disciplina de Matemática. Os gráficos a seguir mostram que, em 2012, o número de alunos abaixo do básico, tanto no Ensino Fundamental quanto no Ensino Médio aumentou consideravelmente, se comparado ao ano anterior.

Verificamos que os alunos que apresentam esse baixo rendimento são provenientes da EMEB (Escola Municipal de Educação Básica), onde por já se encontrarem com idade avançada para a série, são enviados em qualquer condição para a série subsequente do Ciclo II do Ensino Fundamental, sem terem suas dificuldades sanadas, agravando a situação de aprendizagem com os novos conteúdos que deverão ser apresentados.

Já no Ensino Médio, os alunos que chegaram nessa etapa, passaram pela Progressão Continuada, que por falha no processo de avaliação da escola onde não se detectaram os problemas de aprendizagem ao longo do Ciclo ou se detectaram não foram tomadas ações corretivas, fizeram com que os mesmos fossem passando de série em série até serem aprovados ou retidos na oitava série. Se foram aprovados, hoje se encontram abaixo do básico para o Ensino Médio e se foram retidos, estão abaixo do básico na oitava série. 


\section{A inclusão digital do educador}

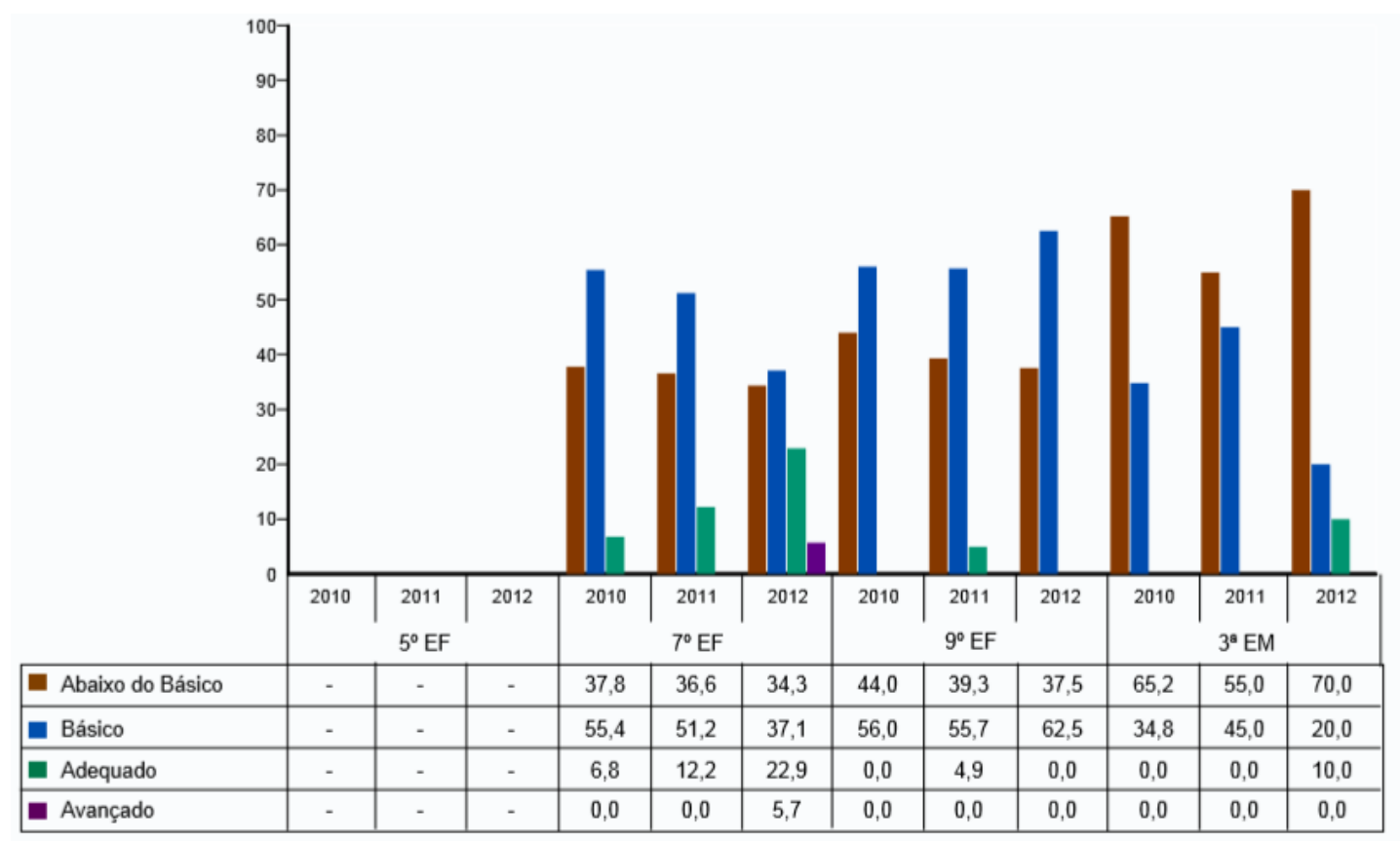

Figura 2.3 - Comparação do percentual de alunos nos níveis da Escala de Proficiência no SARESP 2010 a 2012 - Matemática

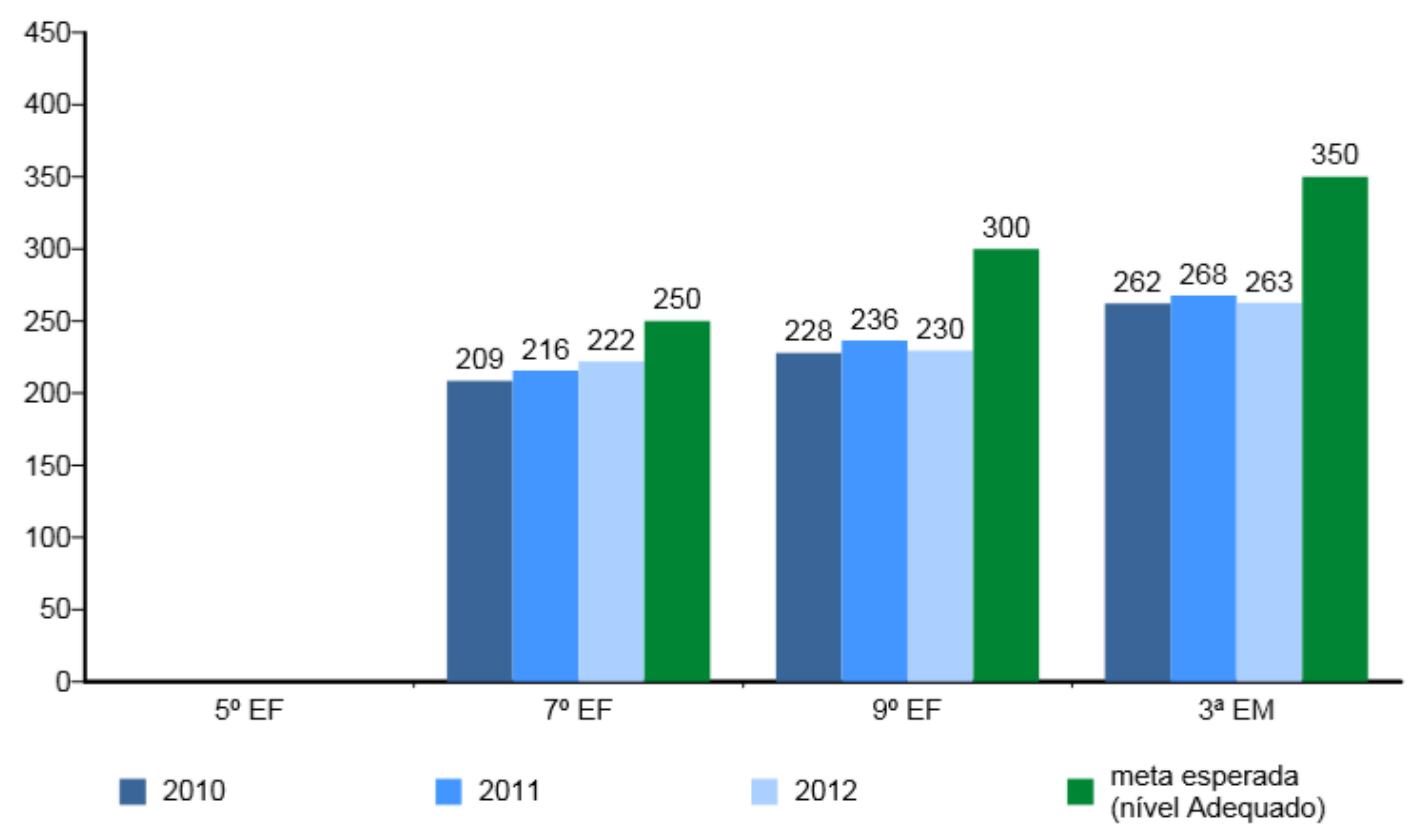

Figura 2.4 - Comparação entre as médias de proficiência dos alunos nas edições de 2010 e 2012 e com a meta esperada no SARESP - Matemática

Por muitas vezes esses alunos demonstram desinteresse, pois, se acham obrigados a acompanhar um conteúdo mais avançado sem ter aprendido o básico. Temos alunos que não conseguem ler ou interpretar, onde então o professor tem que retomar e por muitas vezes ensinar o aluno a ler, outras vezes temos aquele aluno que mal consegue efetuar as quatro operações. O ideal seria que esses alunos viessem para o Ciclo II com essas dificuldades sanadas ou amenizadas, assim todos poderiam enfrentar com menos dificuldades as novas etapas de aprendizagem.

A solução para a questão seria preencher essa lacuna na aprendizagem com aulas diferenciadas e atraentes elevando principalmente 0 aprendizado desses alunos que ficaram abaixo do básico. Através de pesquisas e 
diante do esforço em fazer com que os alunos tenham maior gosto pelas aulas e que consigam de maneira lúdica e interativa compreender conceitos básicos e interpretação de textos, pensamos no uso da sala de informática com maior frequência e no uso de bons softwares.

Esbarramos então na dificuldade enfrentada por nossos professores em lidar com as novas tecnologias e uso de softwares em suas aulas, mas também nos deparamos com uma equipe de professores disposta a aprender e utilizar a sala de informática como mais uma ferramenta a seu favor e a favor do aluno, focando principalmente no índice de alunos abaixo do básico.

A questão de capacitar o professor em seu horário de ATPC tornou-se uma oportunidade de melhoria para nossa escola.

\section{Caracterização do serviço}

\section{Etapa 1 - Conhecendo Novas Ferramentas}

Objetivos pretendidos: Levar o Professor a utilizar os novos conhecimentos para a sala de aula.

Descrição: Essa primeira etapa consistirá em fazer com que o educador se familiarize com ferramentas básicas do Word, fazendo panfletos, pequenos livros, manuseando fotos etc. Em seguida, o professor deverá aplicar seus conhecimentos junto aos alunos e desenvolver trabalhos diversificados com os mesmos.

\section{Etapa 2- Conhecendo e utilizando os Softwares}

Objetivos pretendidos: Professores melhores capacitados influenciando diretamente na aprendizagem de seus alunos.

Descrição: A segunda etapa consistirá em fazer uso dos softwares educacionais e ter conhecimentos dos oferecidos de forma gratuita. Da mesma forma os professores deverão aplicar seus conhecimentos junto aos alunos e desenvolver atividades visando sanar dúvidas e instigá-los a novos conhecimentos.

\section{Etapa 3 - Professor em Rede}

Objetivos pretendidos: estreitar o relacionamento entre professor e aluno através da novas tecnologias.

Descrição: A terceira e última etapa consistirá em ensinar o professor a fazer uso da Nuvem, do Google Drive, redes sociais de forma que ele veja tudo isso como mais uma ferramenta capaz de encurtar as distâncias e tempo.

Nossa proposta é capacitar nossos professores no horário de ATPC para o uso de novas tecnologias e softwares educacionais.

Um profissional capacitado será contratado para efetuar as capacitações com aulas presenciais e a distância. O professor deverá aprender a realizar atividades simples utilizando as ferramentas básicas do Word até a compartilhar dados, copiar fotos, conhecer e fazer uso das redes sociais e plataformas junto aos alunos.

Deixaremos claro para todos os educadores que não basta ter o conhecimento da tecnologia se o educador não tiver a sensibilidade de desenvolver uma boa aula, com desejo e paixão pelo que está fazendo, ou seja, há de se tornar a aula como algo fascinante. Para pessoas que estão longe da realidade escolar, o projeto pode parecer sem importância, por acharem que obviamente todos os educadores sabem lidar com a tecnologia, o que não é verídico.

Em pesquisas realizadas, $70 \%$ dos professores demonstraram não fazer uso da sala de informática da escola por medo de mexer e estragar o computador, ou até mesmo de ter que se submeter a um aluno para tirar dúvidas, pois, ainda há a questão do professor detentor do saber. Estaremos com esse projeto viabilizando maior segurança a esses profissionais e quebrando paradigmas na medida em que ele se veja na condição de eterno pesquisador e aprendiz. 


\section{A inclusão digital do educador}

Especialistas acreditam que não basta equipar escolas, é necessário capacitar educadores principalmente com os chamados softwares livres. Citam ainda que outros softwares ainda trabalham com a ideia antiga de escola onde 0 aluno é o recebedor de informações e o professor é o que repassa as informações, diferente dos softwares livres. Citam também a porcentagem de escolas já equipadas com laboratórios de informáticas que muitas vezes chegam a ser maiores do que o número de bibliotecas (PORTAL TERRA) ${ }^{1}$.

Convém ainda mencionar Bittencourt et al. (2004)² reiteram que o uso das metodologias tecnológicas em sala de aula levam o aluno a "aprimorar a sua capacidade de aprender e de trabalhar de forma colaborativa, solidária, centrada na rapidez e na diversidade qualitativa das conexões e das trocas", aspectos essenciais para a boa convivência na atual sociedade modernizada.

\begin{tabular}{|c|c|c|c|c|c|c|c|c|c|c|c|c|}
\hline \multicolumn{13}{|c|}{$\begin{array}{l}\text { PLANEJAMENTO DE CAPACITAÇÕES EM ATPC / EAD } \\
2014\end{array}$} \\
\hline \multirow{2}{*}{$\begin{array}{l}\text { NOME DOS } \\
\text { PARTICIPANTES }\end{array}$} & \multirow[t]{2}{*}{ ATIVIDADE } & \multirow[t]{2}{*}{ ETAPAS } & \multirow[t]{2}{*}{ HORAS } & \multirow{2}{*}{\begin{tabular}{|l|l|} 
JAI \\
$\mathbf{P}$ & $\mathbf{F}$ \\
\end{tabular}} & \multirow{2}{*}{\multicolumn{2}{|c|}{\begin{tabular}{|l|l|}
\multicolumn{2}{|l}{ FEV } \\
$\mathbf{P}$ & $\mathbf{R}$
\end{tabular}}} & \multirow{2}{*}{ MA } & \multicolumn{2}{|c|}{ ABR } & MAI & \multicolumn{2}{|c|}{ JUN } \\
\hline & & & & & & & & $\mathbf{P}$ & $\mathbf{R}$ & \begin{tabular}{l|l}
$\mathbf{P}$ & $\mathbf{F}$ \\
\end{tabular} & & $\mathbf{R}$ \\
\hline \multirow{3}{*}{$\begin{array}{l}\text { PROFESSORES DO } \\
\text { ENSINO FUNDAMENTAL } \\
\text { E MÉDIO }\end{array}$} & \multirow{3}{*}{$\begin{array}{l}\text { CAPACITAÇÃO DE } \\
\text { PROFESSSORES } \\
\text { PRESENCIAL }\end{array}$} & $\begin{array}{l}\text { Familiarização das ferramentas } \\
\text { básicas do Word; }\end{array}$ & $8 \mathrm{hs}$ & & & & & & & & & \\
\hline & & Uso de Softwares Educacionais & $8 \mathrm{hs}$ & & & & & & & & & \\
\hline & & \begin{tabular}{|l|} 
Uso da Nurem, Google Drive, \\
plataformas diversas, redes sociais
\end{tabular} & $8 \mathrm{hs}$ & & & & & & & & & \\
\hline \multirow{4}{*}{$\begin{array}{l}\text { PROFESSORES DO } \\
\text { ENSINO FUNDAMENTAL } \\
\text { E MÉDIO }\end{array}$} & \multirow{4}{*}{$\begin{array}{l}\text { CAPACITAÇÃO DE } \\
\text { PROFESSSORES EAD }\end{array}$} & & & & & & & & & & & \\
\hline & & $\begin{array}{l}\text { Familiarização das ferramentas } \\
\text { básicas do Word; }\end{array}$ & $8 \mathrm{hs}$ & & & & & & & & & \\
\hline & & Uso de Softwares Educacionais & $8 \mathrm{hs}$ & & & & & & & & & \\
\hline & & \begin{tabular}{|l|} 
Uso da Nurem, Google Drive, \\
plataformas divorsas, rodes sociais
\end{tabular} & $8 \mathrm{hs}$ & & & & & & & & & \\
\hline
\end{tabular}

$P=$ PLANEJADO

R= REALIZADO

Diante do exposto chegamos a conclusão que a capacitação do profissional da educação é o primeiro passo para melhoria dos resultados dos nossos alunos.

Observamos que em momentos anteriores ao projeto, alguns de nossos professores que já conseguiam fazer 0 uso das tecnologias ao seu favor, elaboraram atividades onde os alunos desenvolveram suas habilidades em leitura e escrita produzindo Literatura de Cordel. Fizeram pesquisas sobre 0 assunto na internet $e$ trouxeram para a sala de aula, onde elaboraram os livretos e fizeram impressões dos mesmos para serem distribuídos aos participantes de um evento na escola. Isso foi de grande valor, pois, levou os alunos a aprimorarem suas escritas, a aprenderem a utilizar as ferramentas do Word e a despertar o interesse dos demais professores para a mesma utilização em outras disciplinas.

1 Portal Terra - Notícia sobre a $14^{\text {a }}$ edição do Fórum Internacional Software Livre (FISL) - Porto Alegre/2013. Disponível em: $<$ http://noticias.terra.com.br/educacao/falta-capacitacao-a-professores-para-usar-o-software-livre-nasescolas,6cc6bd46b085f310VgnVCM3000009acceb0aRCRD.html>. Acesso em: 17 out. 2013.

2 BITTENCOURT, C. S.; GRASSI, D.; ARUSIEVICZ, F.; TONIDANDEL, I. Aprendizagem colaborativa por computador. Novas Tecnologias na Educação, v. 2 n. 1, Março/2004, p. 1-5. Disponível em: <http://www.cinted. ufrgs.br/renote/mar2004 /artigos/01-aprendizagem_colaborativa.pdf〉. Acesso em: 17 out. 2013. 

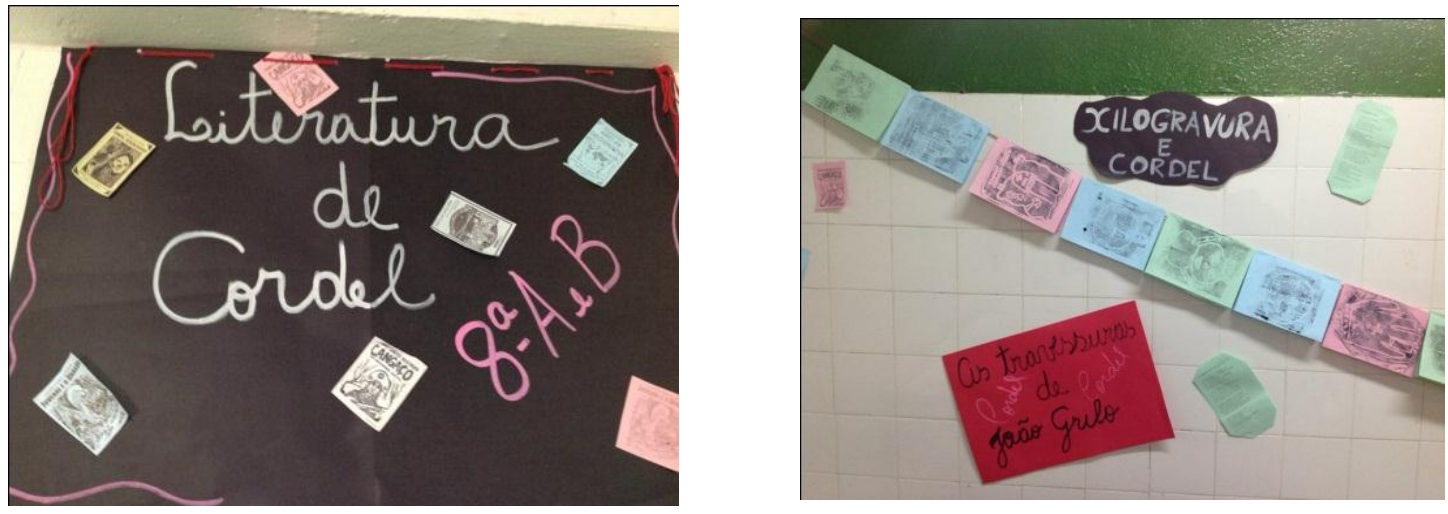

Vendo o interesse dos demais professores, como não fazer algo para que todos tenham a mesma capacidade? O reflexo em aprendizagem é imediato. Alunos demonstram maior interesse nas aulas, pois, têm aprimorado através das tecnologias todos os seus sentidos. Alunos podendo interagir com os exemplos de Física, Química ou mesmo em Arte como presenciei recentemente o Professor Enilson moldando um vaso de barro no Tablet e todos os seus alunos encantados e vendo como se fazia um vaso, algo longe da realidade de todos mas tão presente dentro da sala de aula, ao alcance do aluno.

Visando melhoria nas aulas e aprendizagem, elaboramos o planejamento utilizando a matriz de Swot e a planilha $5 \mathrm{~W} 2 \mathrm{H}$. Com isso poderemos monitorar todas as atividades necessárias para implantação do projeto em si.

\section{Estratégia de implementação Matriz de swot}

\begin{tabular}{|c|c|}
\hline $\begin{aligned} & \text { FORÇAS } \\
& \text { Empresa para capacitações : } \\
& \text { Megaworks Informática / já } \\
& \text { parceira da escola; } \\
&>\text { Professores com perfil } \\
& \text { empreendedor; } \\
&>\text { Professores comprometidos; } \\
&>\text { Escola de informática } \\
& \text { Renomada; } \\
&>\text { Possuir estrutura parcial do } \\
& \text { laboratório de informática; } \\
&>\text { Equipamentos de boa } \\
& \text { qualidade. }\end{aligned}$ & $\begin{array}{l}\text { FRAQUEZAS } \\
>\text { Velocidade lenta da Intemet } \\
\text { Banda Larga oferecida pelo } \\
\text { Governo; }\end{array}$ \\
\hline 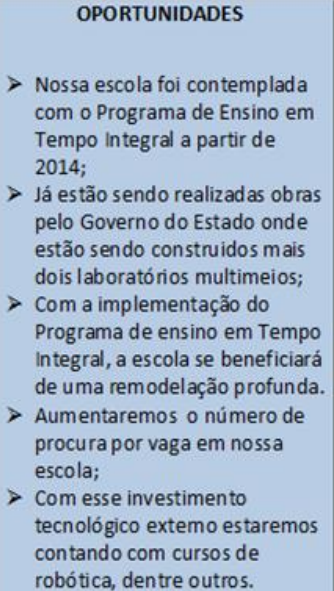 & $\begin{aligned} & \text { AMEAÇAS } \\
& \text { Manutenção constante dos } \\
\text { equipamentos multimídia; } & \text { Segurança do patrimônio. }\end{aligned}$ \\
\hline
\end{tabular}




\section{A inclusão digital do educador}

\section{Objetivos, metas e estratégias...}

\begin{tabular}{|c|c|c|}
\hline OBJETIVOS & METAS & ESTRATÉGIAS \\
\hline $\begin{array}{l}\text { - Melhoria na Aprendizagem } \\
\text { com foco em Língua Portuguesa e } \\
\text { Matemática }\end{array}$ & $\begin{array}{l}\text { - } 100 \% \text { dos professores } \\
\text { capacitados para o uso das novas } \\
\text { tecnologias } \\
\text { - Elevar em } 85 \% \text { o índice das } \\
\text { Avaliações Externas para } 2014\end{array}$ & $\begin{array}{l}\text { - Com uma boa sala de } \\
\text { informática e professores } \\
\text { capacitados para seu uso faremos } \\
\text { com que os alunos tenham maior } \\
\text { interesse pelas aulas uma vez que } \\
\text { a maioria dos seus sentidos } \\
\text { poderão ser estimulados através } \\
\text { de vídeos, pesquisas, interação } \\
\text { com diferentes grupos sempre } \\
\text { mediado por seu professor. } \\
\text { - Caberá ao professor } \\
\text { estimular esse aluno com } \\
\text { atividades extra curriculares } \\
\text { fazendo uso das multimídias. } \\
\text { - Definir e elaborar mostra } \\
\text { dos trabalhos realizados pelos } \\
\text { alunos utilizando imagens, textos, } \\
\text { cálculos e situações problemas. }\end{array}$ \\
\hline
\end{tabular}

Elaboramos a Matriz para o Plano de Ação:

PLANO DE AÇÃO ( 5 W 2 H )

\begin{tabular}{|c|c|c|c|c|c|c|c|c|c|}
\hline \multicolumn{3}{|c|}{$\begin{array}{l}\text { Estratégia / problema: } \\
\text { Necessidade de Capacitação dos Professores }\end{array}$} & \multicolumn{2}{|c|}{$\begin{array}{l}\text { Ultima atualização: } \\
19 / 10 / 2013\end{array}$} & \multicolumn{5}{|c|}{$\begin{array}{l}\text { Meta: Promover Melhorias Continuas na Aprendizagem do } \\
\text { Aluno }\end{array}$} \\
\hline \multicolumn{5}{|l|}{ Área: Informática } & \multicolumn{2}{|c|}{ Data da emissão: 19/10/2013 } & \multicolumn{3}{|l|}{ Aprovado por } \\
\hline O que fazer? & Responsável? & Quando & Onde será feito? & \multicolumn{2}{|c|}{ Porque será feito? } & \multicolumn{2}{|c|}{ Como será feito? } & Custo? & Situação \\
\hline Comprar mais 05 notebooks & Rose & Janeiro & Loja & \multicolumn{2}{|c|}{$\begin{array}{l}\text { Para atender a todos os } \\
\text { professores }\end{array}$} & \multicolumn{2}{|c|}{$\begin{array}{l}\text { Compra de notebooks após } 03 \\
\text { orçamentos }\end{array}$} & SIM & \\
\hline Comprar um roteador & Rose & Janeiro & Loja & \multicolumn{2}{|c|}{ Ampliação de sinal internet } & \multicolumn{2}{|c|}{$\begin{array}{l}\text { Compra de roteador após } 03 \\
\text { orçamentos }\end{array}$} & SIM & \\
\hline Comprar Sofwares Educacionais & Rose & Janeiro & Loja & \multicolumn{2}{|c|}{$\begin{array}{l}\text { Para conhecimento e uso } \\
\text { do Professor }\end{array}$} & \multicolumn{2}{|c|}{$\begin{array}{l}\text { Um sofware para cada } \\
\text { disciplina }\end{array}$} & SIM & \\
\hline Compra de impressora & Carmen & Janeiro & Loja & \multicolumn{2}{|c|}{ Para Impressão } & \multicolumn{2}{|c|}{$\begin{array}{l}\text { Compra de impressora após } 03 \\
\text { orçamentos }\end{array}$} & SIM & \\
\hline Compra de tintas & Vaneide & Janeiro & Site & Para In & ressão & Através de sit & & SIM & \\
\hline Compra de limpressora & Lelian & Janeiro & Site & Para In & oressão & Através de sit & & SIM & \\
\hline Contratação de um Profissional & Vaneide & Janeiro & $\begin{array}{l}\text { Megaworks } \\
\text { /Informática }\end{array}$ & Para re & lizar a capacitação & Utilizando AT & & SIM & \\
\hline $\begin{array}{l}\text { Instalação de Projetor na sala de } \\
\text { Informática }\end{array}$ & $\begin{array}{c}\text { Empresa } \\
\text { Diretriz }\end{array}$ & Janeiro & $\begin{array}{l}\text { Na sala de } \\
\text { informática }\end{array}$ & $\begin{array}{l}\text { Facilite } \\
\text { amplia }\end{array}$ & $\begin{array}{l}\text { capacitação e } \\
\text { a interação do aluno }\end{array}$ & Fixando proje & tor no teto & SIM & \\
\hline & & & & & & & & & \\
\hline & & & & & & & & & \\
\hline & & & & & & & & & \\
\hline & & & & & & & & & \\
\hline Legenda de status da situação. & & & & & & & & & \\
\hline Em andamento & Equipe de traba & alho: & Rose / Carmem / Va & aneide / & elian & & & & \\
\hline Concluido & & & & & & & & & \\
\hline Parado & & & & & & & & & \\
\hline Atrasado & & & & & & & & & \\
\hline Não iniciado & & & & & & & & & \\
\hline
\end{tabular}




\section{Marketing e comunicação}

Sem sombra de dúvidas um professor bem capacitado, estimulado e amparado promoverá mudanças em suas aulas, mudanças essas capazes de elevarem a aprendizagem e os índices de avaliações externas e internas. Fará com que seu aluno seja mais um descobridor de novos caminhos auxiliando-o a reconhecer 0 que há de útil nas redes sociais e diversos sites. Levará esse aluno a romper fronteiras do aprendizado onde em contato com novas culturas ou sociedades se verá frente a oportunidades de vida. Fazer 0 aluno ser autor das suas ideias, colocá-las em prática do bem comum, despertar no aluno a curiosidade tão latente nos jovens, promover sonhos, compartilhar saberes com sua família é o que pretendemos com esse projeto.

A capacitação causará impacto na maneira como esse professor elaborará suas aulas, pois, se sentirá mais seguro constatando a facilidade para promover e desenvolver atividades onde 0 aluno possa interagir inclusive através dos seus celulares, embora , trata-se de uma comunidade carente o celular com internet é realidade presente e não aproveitada pelos educadores.

Recentemente, quando os mesmos professores citados anteriormente, já familiarizados com as diversas formas tecnológicas, elaboraram uma atividade onde os alunos deveriam sair pelas ruas dos bairros onde moravam, fotografar, filmar e colher depoimentos em entrevistas cujo tema foi "Os perigos da Rede Elétrica", houve um grande envolvimento dos alunos das séries finais do Ciclo II e Ensino médio. Com auxílio dos professores fizeram vídeos elaborados e entrevistas detalhadas com moradores da comunidade sobre acidentes com a rede elétrica. $O$ que quero demonstrar com isso é que não foi mais um texto passado pelo professor detentor do saber e copiado pelo aluno recebedor de informações. Foi algo maior, real, oportuno. Fez os alunos enxergarem os riscos envolvendo seus familiares e comunidade.

\section{Situação irregular, fotografaram "gatos"...}

\section{Situação Regular}
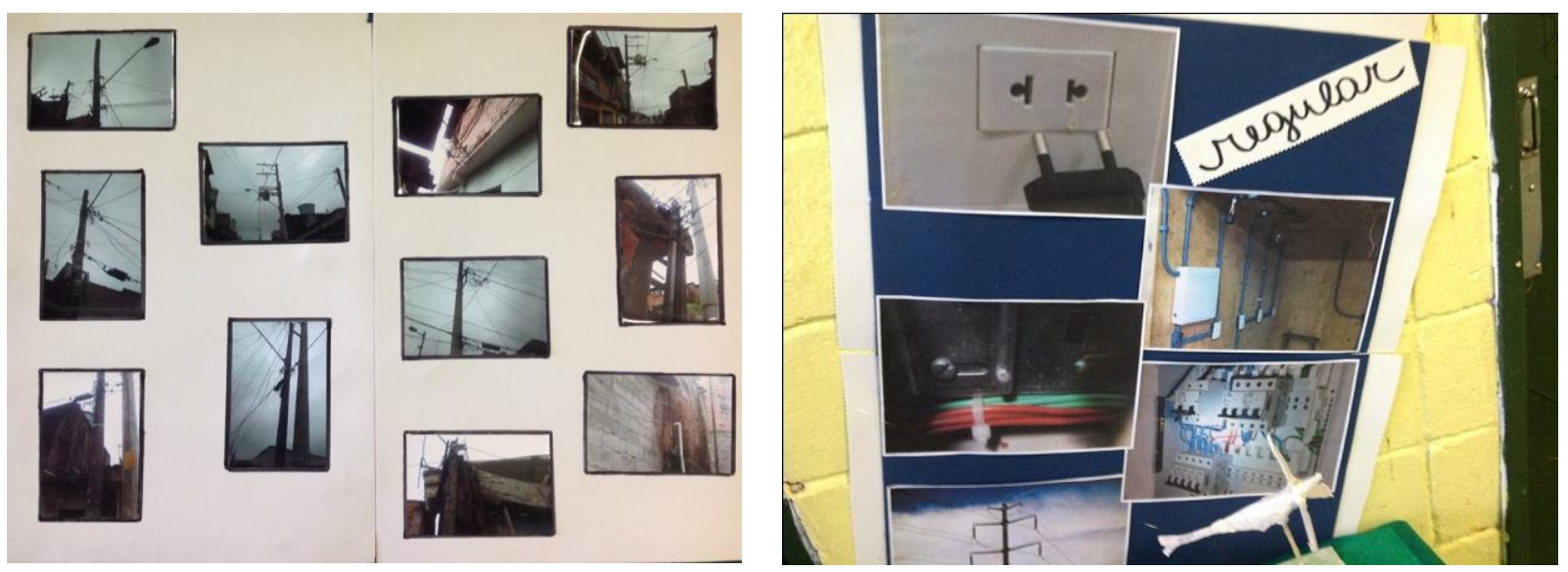

Em nossa página do Facebook estão divulgados alguns dos trabalhos realizados na EE Jean Piaget . Planejamos promover um encontro entre a empresa interessada em financiar nosso projeto e a equipe gestora juntamente com a supervisora de ensino.

Por se tratar de uma demanda latente, com esse projeto estaremos atendendo as necessidades dos nossos alunos com um trabalho eficaz e assim satisfazendo os desejos das famílias em manter seus filhos em uma escola que se preocupa com a qualidade de ensino dos seus filhos. Terão oportunidades de conhecer nossa escola, nossos alunos e professores e desta forma sentir a potencialidade que temos para nos tornarmos uma escola de referência em Educação.

\section{Organização e gerência do empreendimento}




\section{A inclusão digital do educador}

A EE Jean Piaget conta hoje com uma equipe muito unida. Todos os membros possuem Pedagogia e cursos voltados para o empreendedorismo. São pessoas determinadas e principalmente motivados. Doi dos membros são especialistas na área de Matemática o que facilita o trabalho nessa área com baixo rendimento

\section{Fluxo de processo do projeto}

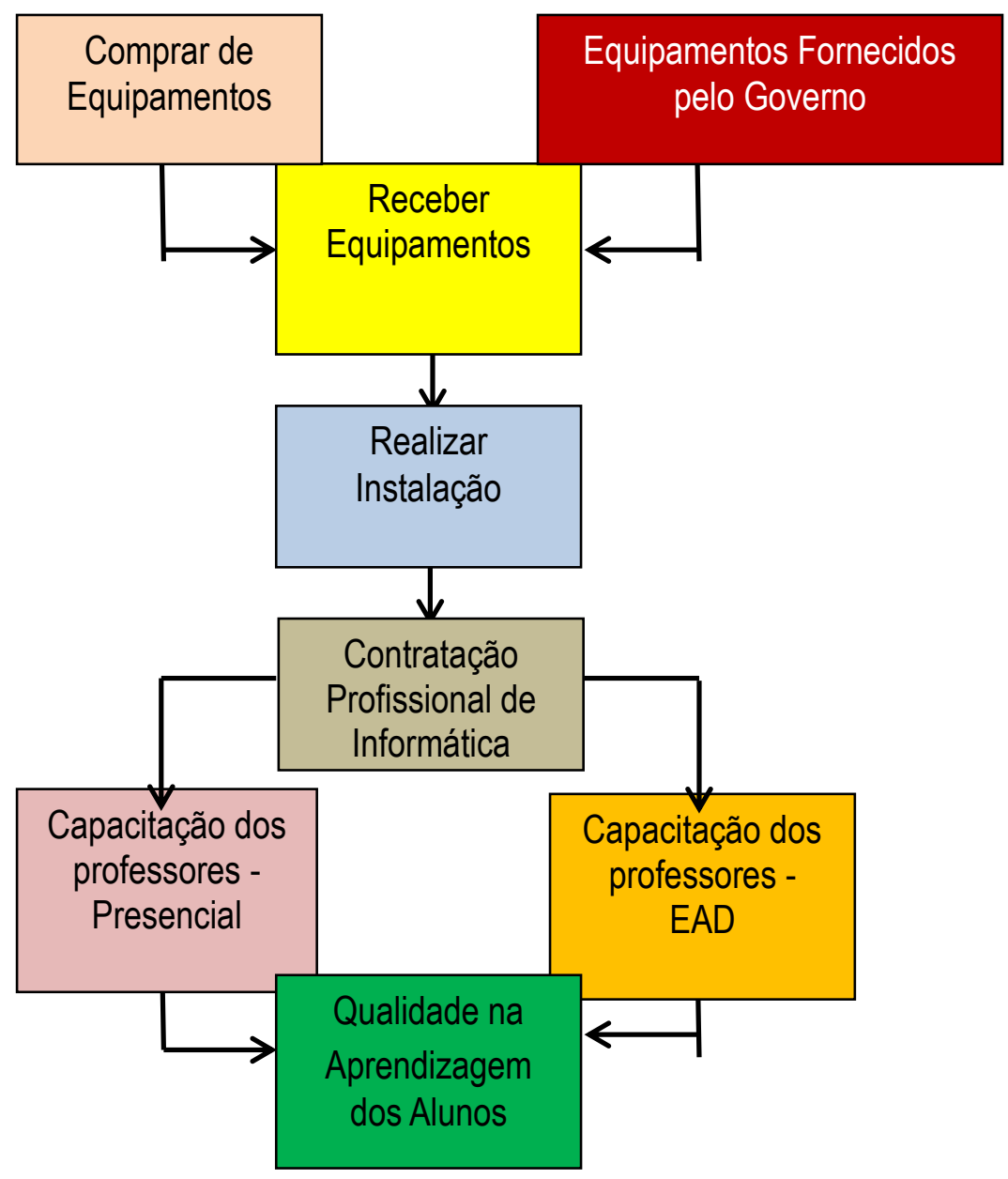

\begin{tabular}{|c|}
$\begin{array}{c}\text { Compra de } \\
\text { Equipamentos }\end{array} \longrightarrow \begin{array}{l}\text { Realizar compras dos equipamentos necessários através de } \\
\text { consulta de três fornecedores com seus respectivos } \\
\text { orçamentos. } \\
\text { Nota: fornecedores devem possuir seu CNPJ Ativo. }\end{array}$ \\
\hline
\end{tabular}

Equipamentos

Fornecidos pelo

Governo
Realizar compras dos equipamentos necessários através de consulta de três fornecedores com seus respectivos orçamentos.

Nota: fornecedores devem possuir seu CNPJ Ativo. 
Rose Rodrigues Silva Morelli

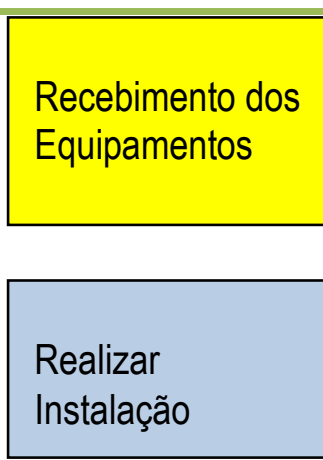

Realizar compras dos equipamentos necessários através de consulta de três fornecedores com seus respectivos orçamentos.

Nota: fornecedores devem possuir seu CNPJ Ativo.

Realizar compras dos equipamentos necessários através de consulta de três fornecedores com seus respectivos orçamentos.

Nota: fornecedores devem possuir seu CNPJ Ativo.
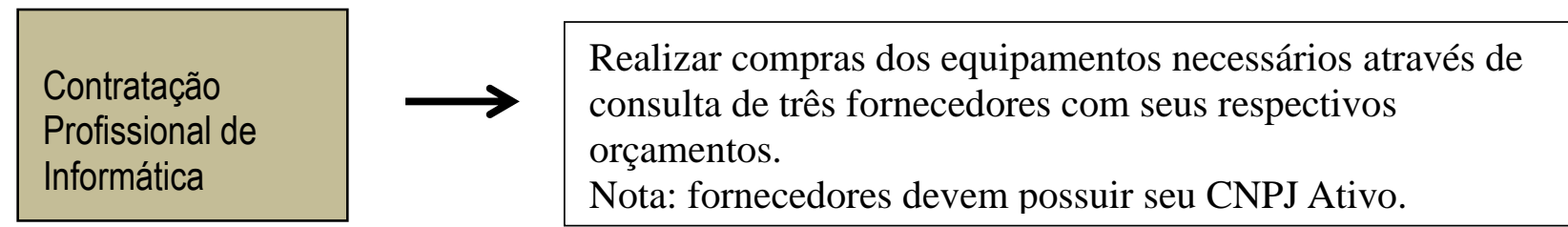

Realizar compras dos equipamentos necessários através de consulta de três fornecedores com seus respectivos orçamentos.

Nota: fornecedores devem possuir seu CNPJ Ativo.

\section{Capacitação dos} professores

\section{Capacitação dos} professores
Realizar compras dos equipamentos necessários através de consulta de três fornecedores com seus respectivos orçamentos.

Nota: fornecedores devem possuir seu CNPJ Ativo.
Qualidade na

Aprendizagem dos

Alunos
Realizar compras dos equipamentos necessários através de consulta de três fornecedores com seus respectivos orçamentos.

Nota: fornecedores devem possuir seu CNPJ Ativo.

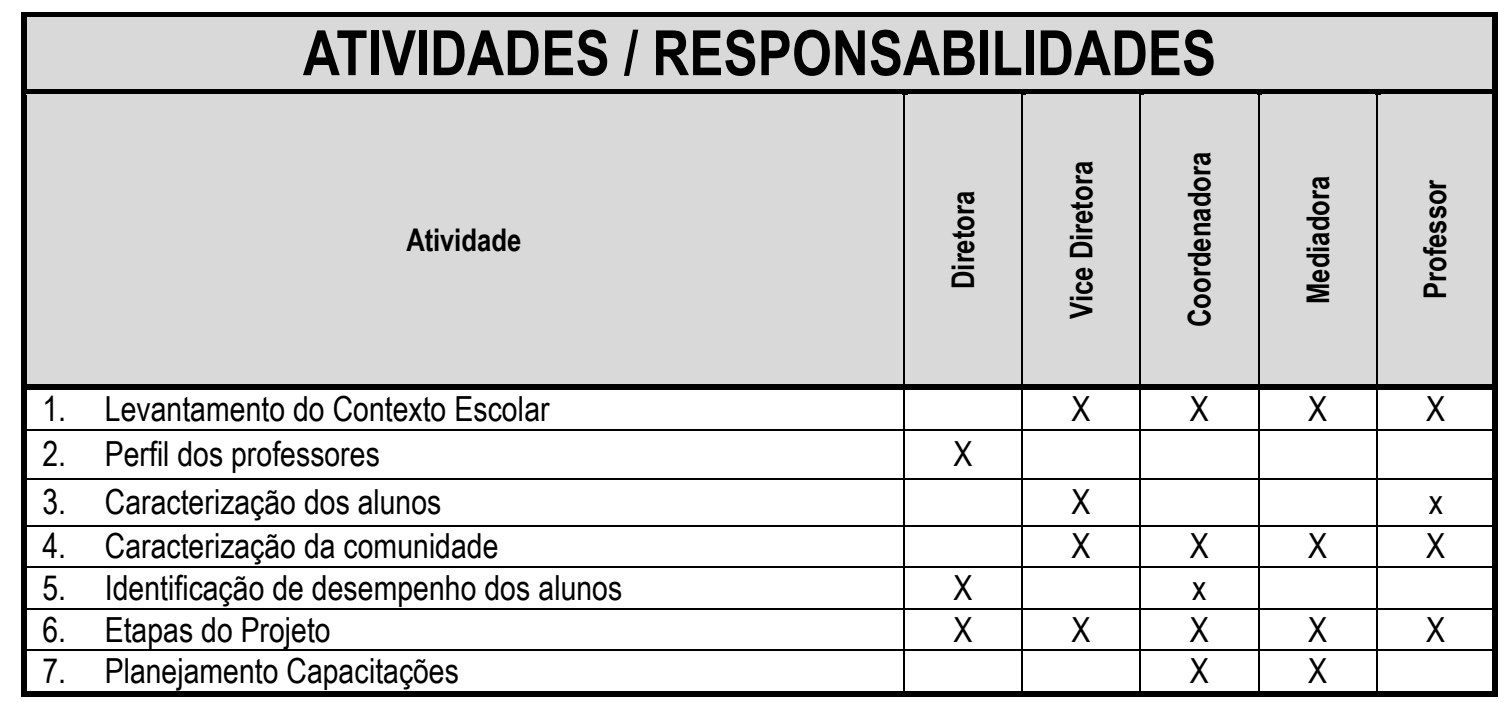




\section{A inclusão digital do educador}

\begin{tabular}{|c|c|c|c|c|c|}
\hline 8. Matriz Swot & $\bar{x}$ & $\bar{x}$ & $\bar{x}$ & $\bar{X}$ & $\bar{x}$ \\
\hline 9. Objetivos, Metas e Estratégias & $\mathrm{X}$ & $\mathrm{X}$ & $\mathrm{X}$ & $\mathrm{X}$ & $\mathrm{X}$ \\
\hline 10. Plano de Ação 5W2H & $\mathrm{X}$ & $\mathrm{X}$ & & & \\
\hline 11. Marketing e Comunicação & $\mathrm{X}$ & & & $\mathrm{X}$ & $\mathrm{x}$ \\
\hline 12. Missão e Visão & $x$ & $\mathrm{X}$ & & & \\
\hline 13. Capacitação dos Professores & $\mathrm{X}$ & $\mathrm{X}$ & $\mathrm{X}$ & & \\
\hline 14. Aquisição de Equipamentos & $\mathrm{X}$ & & & & \\
\hline 15. Recebimento dos Equipamentos & $\mathrm{X}$ & $\mathrm{X}$ & $\mathrm{X}$ & $\mathrm{X}$ & \\
\hline 16. Instalação equipamentos & & $\mathrm{X}$ & & & \\
\hline 17. Contratação do Profissional para capacitação & & & $\mathrm{X}$ & & \\
\hline 18. Monitorar qualidade da aprendizagem & $\mathrm{X}$ & $\mathrm{X}$ & $\mathrm{X}$ & $\mathrm{X}$ & $\mathrm{X}$ \\
\hline
\end{tabular}

DESCRIÇÃO DE FUNÇÃO

Página 129 de 4

\section{Função: Diretor}

\section{Descrição da função}

ATIVIDADES RELACIONADAS A FUNÇÃO:

Gerenciamento da parte pedagógica ;

> Gerenciamento da parte financeira da Instituição;

> Gerenciamento dos recursos humanos;

Atendimento aos pais;

- Acompanhamento das ATPCs;

$>$ Acompanhamento de aulas;

$>$ Mediação entre alunos;

> Responsável pelas manutenções preventivas e corretivas da escola;

$>$ Acompanhamento de merenda;

> Compra de materiais para escritório e para eventos;

Participa de reuniões na Diretoria de ensino e com supervisor;

Dlabora prestação de contas da escola para o Governo Estadual e Federal;

\begin{tabular}{|l|l|}
\hline \multicolumn{1}{|c|}{ Experiência } & \multicolumn{1}{|c|}{ Perfil } \\
\hline$>$ Formada em Pedagogia na FASB & $>\begin{array}{l}\text { Empreendedor, mediador , com 28 } \\
\text { em São Bernardo, com Pós- } \\
\text { Graduação em Gestão }\end{array}$ \\
$\begin{array}{l}\text { Educacional pela Unicamp. } \\
\text { Educação entre sala de aula e } \\
\text { administração na rede pública de } \\
\text { São Paulo. }\end{array}$ \\
\end{tabular}




\section{DESCRIÇÃO DE FUNÇÃO}

\section{Função: Vice Diretor}

\section{Descrição da função}

ATIVIDADES RELACIONADAS A FUNÇÃO:

Auxiliar diretamente o diretor em todas as funções ;

> Gerenciar financeiramente a merenda bem como seu preparo;

> Mediar conflitos entre alunos;

Atender pais ;

Acompanhar aulas e suas devidas substituições;

> Monitorar manutenção predial.

\begin{tabular}{|c|c|}
\hline Experiência & Perfil \\
\hline $\begin{array}{l}\text { Trabalhou por mais de dez anos } \\
\text { em empresa sendo secretária da }\end{array}$ & $>$ Empreendedor, mediador e apoiador. \\
alta diretoria de uma empresa de \\
tintas até migrar para a área da \\
Educação onde está atuando \\
entre sala de aula e administração \\
escolar há mais de 10 anos.
\end{tabular}




\section{A inclusão digital do educador}

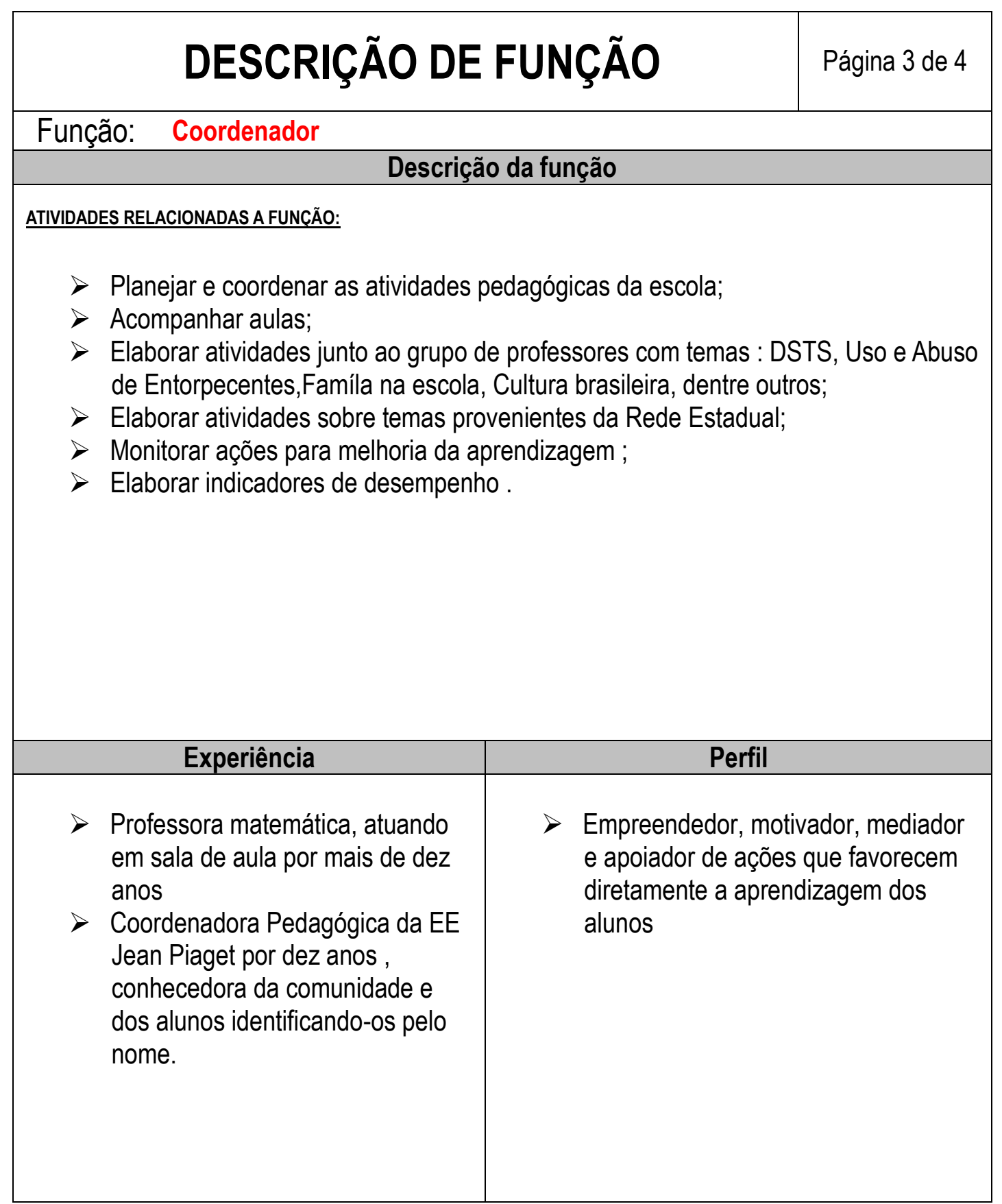




\section{DESCRIÇÃO DE FUNÇÃO}

\section{Função: Mediadora}

\section{Descrição da função}

ATIVIDADES RELACIONADAS A FUNÇÃO:

Faz intervenção direta junto a família do aluno e Conselho Tutelar

- Media conflitos e estabelece regras de convivência

$>$ Acompanha aula;

$>$ Atua juntamente com o coordenador Pedagógica nas diversas ações educacionais.

$>$ Elabora meios de monitorar evasão escolar

\begin{tabular}{|l|l|}
\hline \multicolumn{1}{|c|}{ Experiência } & \multicolumn{1}{|c|}{ Perfil } \\
\hline$>\begin{array}{l}\text { Professora na área de } \\
\text { matemática. }\end{array}$ & $>$ Empreendedor, mediador, apoiador. \\
$>\begin{array}{l}\text { Atuou alguns anos na área de } \\
\text { coordenação do Programa Escola } \\
\text { da Família Governo Estadual }\end{array}$ & \\
$>\begin{array}{l}\text { Atua como mediadora na EE Jean } \\
\text { Piaget . }\end{array}$ & \\
& \\
\end{tabular}

\section{Plano Financeiro}

\section{Investimento (Despesa de Capital)}

\begin{tabular}{|l|c|c|c|}
\hline \multicolumn{1}{|c|}{ Item } & Ano1 & Ano2 & Ano3 \\
\hline \multicolumn{1}{|c|}{ Obras e infraestrutura } & $\mathbf{0 , 0 0}$ & $\mathbf{0 , 0 0}$ & $\mathbf{0 , 0 0}$ \\
\hline Obras & 0,00 & 0,00 & 0,00 \\
\hline Instalações & 350,00 & 0,00 & 0,00 \\
\hline \multicolumn{1}{|c|}{ Material permanente } & $\mathbf{1 1 . 7 0 1 , 9 4}$ & $\mathbf{0 , 0 0}$ & $\mathbf{0 , 0 0}$ \\
\hline $\begin{array}{l}\text { Nobreak SMS Manag Net4 + } \\
\text { 700Bi }\end{array}$ & 371,79 & & \\
\hline $\begin{array}{l}\text { Computadores DELL Urban } \\
\text { 2.0 DEL (5 notebooks) }\end{array}$ & $9.716,10$ & & \\
\hline Impressora HP & $1.614,05$ & & \\
\hline Total & $\mathbf{1 1 . 7 0 1 , 9 4}$ & $\mathbf{0 , 0 0}$ & $\mathbf{0 , 0 0}$ \\
\hline
\end{tabular}




\section{A inclusão digital do educador}

\section{Despesas correntes}

\begin{tabular}{|c|c|c|c|}
\hline \multicolumn{4}{|c|}{ Projeção das Despesas Correntes } \\
\hline Material de Consumo & Total ANO 1 & Total ANO 2 & Total ANO 3 \\
\hline Tintas & 600,00 & 600,00 & 600,00 \\
\hline Sulfites & 900,00 & 900,00 & 900,00 \\
\hline Softwares & - & - & - \\
\hline Total & 1500,00 & 1500,00 & 1500,00 \\
\hline Passagens e Locomoção & Total ANO 1 & Total ANO 2 & Total ANO 3 \\
\hline & 0 & 0 & 0 \\
\hline Total & 0 & 0 & 0 \\
\hline Serviços de Terceiros & Total ANO 1 & Total ANO 2 & Total ANO 3 \\
\hline Professor & $2.017,59$ & $2.118,47$ & $2.182,95$ \\
\hline Instalação & - & $1.050,00$ & $1.050,00$ \\
\hline Total & $2.017,59$ & $3.168,47$ & $3.232,95$ \\
\hline Total das Despesas Correntes & $3.517,59$ & $4.668,47$ & $4.732,95$ \\
\hline
\end{tabular}

\section{Detalhamento:}

- Tintas Para Impressora HP Wireless 2546 Multifuncional;

- Softwares Educacionais de concepção construtivista para Matemática e Língua Portuguesa que levem o aluno a maior interação.

- Para a execução da capacitação contrataremos um Professor Técnico Administrativo da Empresa Megaworks já parceira da escola.

- O pagamento deste profissional será feito pela APM ( Associação de Pais e Mestres com recursos próprios );

- Chegamos ao valor do Salário através de pesquisa no sindicato dos professores no site do Sinpro, utilizando a tabela de cálculos para professor aulista técnico em informática.

- A instalação dos equipamentos na sala de informática ficará por conta da empresa Diretriz que faz o melhor preço e com qualidade de serviço. 


\section{Despesas administrativas e de pessoal *VALOR UTILIZADO COMO CONTRAPARTIDA}

\begin{tabular}{|c|c|c|c|}
\hline \multicolumn{4}{|c|}{ Projeção das Despesas Administrativas e de Pessoal } \\
\hline Administrativas & Total ANO 1 & Total ANO 2 & Total ANO 3 \\
\hline Despesas com água & 824,67 & 844,05 & 860,91 \\
\hline Despesas com luz & 668,28 & 709,58 & 752,16 \\
\hline Despesas com telefone/Internet & 391,32 & 417,97 & 447,21 \\
\hline Total & $1.884,27$ & $1.971,60$ & $2.060,28$ \\
\hline Pessoal & Total ANO 1 & Total ANO 2 & Total ANO 3 \\
\hline Um Professor Técnico Informática & $1.345,06$ & $2.118,47$ & $2.224,38$ \\
\hline Total & $1.345,06$ & $2.118,47$ & $2.224,38$ \\
\hline Total das Despesas Adm + Pessoal & $3.229,33$ & $4.090,07$ & $4.284,66$ \\
\hline
\end{tabular}

\section{Detalhamento}

O Professor Técnico em Informática receberá seu pagamento de acordo com os cálculos feito no site do sindicato da categoria SINPRO. Realizamos o cálculo por aulas que serão dadas e o tempo livre conforme explicação a seguir:

Salário base: número e aulas semanais multiplicado por 4,5semanas. 0 resultado encontrado é 0 total de aulas que deve ser multiplicado pelo valor hora-aula.

Hora Atividade: $5 \%$ destinado ao pagamento do professor para a preparação das aulas e correções de provas e atividades. Para calcular multiplique 0 salário base pelo percentual de hora-atividade. 0 percentual deve ser pago no décimo terceiro, férias e recesso.

Descanso semanal remunerado: corresponde a 1/6 sobre a remuneração total, devendo ser calculado sobre a soma do salário base, da hora atividade, das horas extras e demais adicionais e essa discriminação é obrigatória no holerite dos professores aulistas. Disponivel em http://www.sinprosp.org.br/guia_consultas.asp?mat=68 


\section{A inclusão digital do educador}

\section{Necessidade de recursos}

\begin{tabular}{|l|c|c|c|c|}
\hline \multicolumn{4}{|c|}{ Cálculo da Necessidade de Recursos } & \\
\hline \multicolumn{1}{|c|}{ Item } & ANO 1 & ANO 2 & ANO 3 & TOTAL \\
\hline I. Total das Despesas Correntes & $\mathbf{3 . 5 1 7 , 5 9}$ & $\mathbf{4 . 6 6 8 , 4 7}$ & $\mathbf{4 . 7 3 2 , 9 5}$ & $\mathbf{1 2 . 9 1 9 , 0 1}$ \\
\cline { 1 - 5 } Material de Consumo & $1.500,00$ & $1.500,00$ & $1.500,00$ & $4.500,00$ \\
\hline Passagens e Despesas com Locomoção & 0,00 & 0,00 & 0,00 & 0,00 \\
\cline { 1 - 5 } Serviços de Terceiros & $2.017,59$ & $3.168,47$ & $3.232,95$ & $8.419,01$ \\
\hline II. Total de Despesas Administrativas & $\mathbf{1 . 8 8 4 , 2 7}$ & $\mathbf{1 . 9 7 1 , 6 0}$ & $\mathbf{2 . 0 6 0 , 2 8}$ & $\mathbf{5 . 9 1 6 , 1 5}$ \\
\cline { 1 - 5 } III. Total de Despesas com Pessoal & $\mathbf{1 . 3 4 5 , 0 6}$ & $\mathbf{2 . 1 1 8 , 4 7}$ & $\mathbf{2 . 2 2 4 , 3 8}$ & $\mathbf{5 . 6 8 7 , 9 1}$ \\
\hline IV. Total de Despesas de Capital (investimentos) & $\mathbf{1 1 . 7 0 1 , 9 4}$ & $\mathbf{0 , 0 0}$ & $\mathbf{0 , 0 0}$ & $\mathbf{1 1 . 7 0 1 , 9 4}$ \\
\hline Necessidade de Recursos (I+II+III+IV) & $\mathbf{1 8 . 4 4 8 , 8 6}$ & $\mathbf{8 . 7 5 8 , 5 4}$ & $\mathbf{9 . 0 1 7 , 6 1}$ & $\mathbf{3 6 . 2 2 5 , 0 1}$ \\
\hline Recursos Edital & $15.219,53$ & $4.668,47$ & $4.732,95$ & $\mathbf{2 4 . 6 2 0 , 9 5}$ \\
\hline Recursos da Organização (contrapartida) & $3.229,33$ & $4.090,07$ & $4.284,66$ & $\mathbf{1 1 . 6 0 4 , 0 6}$ \\
\hline
\end{tabular}

